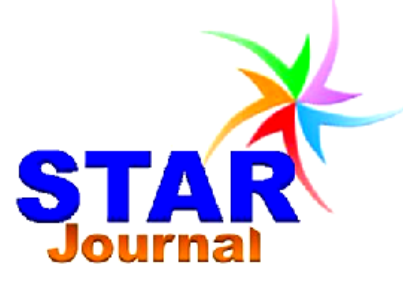

\author{
ISSN: 2226-7522(Print) and 2305-3327(Online) \\ Science, Technology and Arts Research Journal \\ Oct-Dec 2012, 1(4):95-102 \\ www.starjournal.org \\ Copyright@2012 STAR. All Rights Reserved
}

Original Research

\title{
Challenges and Prospects for Promotion of International Tourism in Ethiopia: A Case Study of Bahir Dar
}

\author{
Dharmendra Kumar Dube
}

\author{
School of Natural Resource Management and Environmental Sciences, Haramaya University, \\ Haramaya, Ethiopia
}

\section{Abstract}

It is a case study to assess the potential and challenges of tourism development in Bahir Dar, Ethiopia, through the view point of international tourists. Study covers the tourist spots of in and around Bahir Dar town, Blue Nile falls and island monasteries of Lake Tana. Information was gathered from 165 international tourists, randomly selected. A questionnaire was developed and used for tourists, and interviews were taken from the local professionals in the industries. Descriptive statistical techniques were used for the analysis of the data. The general trend of tourism shows growth in Ethiopia as well as in Bahir Dar but not with the expected rate. Among the foreign tourists visiting Bahir Dar, 60 percent are male. It seems to be a major destination for youth and middle aged people $(72.72 \%)$ but not significant for children $(3.66 \%)$ and families $(5.46 \%)$. Maximum tourists are coming from the countries of Europe $(30.9 \%)$ and North America (27.27\%). Internet (34\%) and books (32\%) are the prime source of information. A large number of old aged tourists $(21.31 \%)$, and visits more than one time $(44.24 \%)$ are the unique feature of this tourist destination, which express its potential of tourism and secure social environment. Lake Tana is the prime attraction among tourists and visited with boat by all. Visit to lake Tana is the first priority among the tourists. As we go deep into this huge lake, the frequency of tourists drastically decreases. Spot-II, 'Zige Peninsula and Narga Salase Monastery' in Daq Island is visited by only $12.73 \%$ tourists and Spot-III 'crossing the lake at Gorgora' by just $5.45 \%$ only, however there priority of liking remains in tacked with the deeper destinations. A big gap was observed in projection of spots by tourists' authorities and appreciation by visitors. Blue Nile Falls and Traditional Orthodox Church School are the glaring examples. Study recommends the update, accurate and detailed information through internet and books. Projection of the spots in tourism information network should base upon the liking and disliking of tourists.
\end{abstract}

\section{INTRODUCTION}

Tourism is among the fastest growing industry of the world which accounts for a higher share of world trade than cars or oil. It is the main stay of economy for many small developing countries. Being highly labour intensive, this sector provides vital employment for native people.

Tourism has become a popular global leisure activity. In 2010, there were over 940 million international tourist arrivals, with a growth of $6.6 \%$ as compared to 2009 . International tourism receipts grew to US\$919 billion in 2010, corresponding to an increase in real terms of
$4.7 \%$ (UNWTO, 2010). Tourism is not ubiquitous activity and so the growth of it. Unfortunately it is a unequally distributed activity depicting some sharp glazy nodes and wide shadow areas on globe, and so the sharply varied shares of profit going to varied countries. On an average largest number of tourists are coming from developed or fast developing countries; most of the tourists attractions are also falling and developed in these countries only, and finally they are the countries who are fetching the largest share of benefits from this fastest growing industry. Despite of their pristine natural beauty and rich cultural heritage, the poor developing and underdeveloped 


\section{Dharmendra Kumar Dube}

countries, especially from Africa is far lagging behind in drawing benefit of this growing sector (EEA, 2007).

Most African countries including Ethiopia, encouraging the tourism sector for their ability to generate employment opportunity, source of foreign exchange and revenue for government and for local communities, and for its diversifying effect in regional and national income.

Ethiopia, located on the 'horn of Africa', is the largest elevated landmass in Africa. More than $50 \%$ of its huge land mass is above $1000 \mathrm{msl}$, and also known as the 'Roof of East Africa' or 'water tower of East Africa'. Ethiopia is known for its ancient civilization and rich diversified cultural heritage. For anthropologist it is known as the 'cradle of humanity' while for geologist it an 'living laboratory'. It is the country of numerous natural and manmade tourist attractions. It is the home of various tribes with diverse language, culture, lifestyle and traditions. It could be said without doubt that Ethiopia has tremendous attractive destinations for tourist. Government and people both want to develop tourism yet it has not become a hot spot for on international tourist map.

The major tourist attractions in Ethiopia could be put under four circles-

1. The western historical circle-

2. The Eastern Historical circle.

3. The Lakes circle of Rift Valley.

4. The South Western region.

Out of these four major regions the western historical circle is the most important which includes the major tourist attractions of Ethiopia. Starting from the capital Addis Ababa it includes the rock cut churches of Lalibela, The castle city of Gonder, The Axum, Makele, Dessi, and the Semin Mountains and the lake city of Bahir Dar.

Bahir Dar, with a population of 0.17 million, located $576 \mathrm{Km}$. north-west from Addis Ababa on Addis-Gonder highway. This small, well planned and among fastest growing town of Ethiopia, is the capital of Amhara National Region State (ANRS), one of the nine national regions of the Federal Democratic Republic of Ethiopia.

Bahir Dar is situated on the southern tip of Lake Tana, at the origin point of river Blue Nile (Ethiopian name- Abbey). Almost 1800M above $\mathrm{msl}$, it is a tourist town with beautiful natural surrounding and soothing climate, and geared up with all basic facilities required for a tourist town. Bahir Dar is the not only the prominent
Sci. Technol. Arts Res. J., Oct-Dec 2012, 1(4):95-102

destination on the Western Historical Circle (WHC) but also the base for the boat expeditions into massive Lake Tana.

Bahir Dar, blessed with Lake Tana and Blue Nile is itself a pleasant destination, yet its major tourist attractions could be categorized as follows-

A. Attractions in Lake Tana- Lake Tana is the largest body of water of Ethiopia, with about an area of 3,000 squire-kilometers, roughly it is 75 kilometers long and 65 kilometers broad. Lake is spotted with 37 scattered islands, some twenty out of which shelters churches and monasteries of significant historical importance. As per tourist point of view the attractions within lake could be numbered as follows-

- Side walk to lake

- Mango Park and short trip to lake without touching any destination

- Origin of river Blue Nile and Debre Maryam church with Hippo point

- Nearest two islands with churches -Entos Eyesu and Kebran Gabriel Monastery.

- Zeghe peninsula and Ura Kidane Mehret Monastery.

- Narga Selasi and Dega Estefanos Monastery.

- Across the Lake trip, Trip to Gorgora

B. Attractions along the river Blue Nile-

- Origin of river Blue Nile

- Blue Nile Water Fall (tis-isat)

- War Memorial

- Haile Selasi Palace and Hippo point.

C. Attractions in and around City-

- St. Georgis Church

- The Market

- Traditional Church School

The basic question of study is why Ethiopia in general and Bahir Dar in particular not able to exploit even the fraction of the immense potential of tourism they have and to know the present status of international tourism in Bahir Dar. Weather there is dissimilarity between the government's projection of tourist attractions and tourist likings for them. Unlike earlier studies, this work is based on tourists' perception. Visit to lake Tana was not considered as a single attraction. The two major questions were dealt thoroughly in present study, they are 'why tourist visit Bahir Dar' and 'why not most of them go deep into Lake Tana'. Finally to identify the major challenges for the development of tourism and finding suitable solutions. 
Dharmendra Kumar Dube

\section{MATERIALS AND METHODS}

This is an empirical study. To undertake this study, survey research method was used. Ranking methods were deployed to know the tourist perception about different tourists spots in the study area. For analysis and description of the data, simple descriptive techniques were used.

\section{Sample Size and Sampling Techniques}

Random sampling technique was used to select the responds. In total 165 tourists were surveyed during the main tourist season of the area. Perhaps your point number 3 under delimitation should come here. The ones you mention as region, religion, age, gender are known as 'sampling traits or sampling criteria'. You are not explaining the sampling techniques you used. I mean, you must explain how did you go about doing this sampling process. If sampling is possible at all in this particular study. Sampling should talk about selecting from a 'universe'. What is your 'universe'?

\section{Data collection Instrument}

Both open and closed-ended questions were developed and used to gather data for the study. An interview schedule was also developed to interview the professionals in this profession at Bahir Dar.

\section{Data Collection and Statistical Treatment}

Data was collected from Questioner and one Interview Schedule. Questionnaire was used to gather data from one hundred and sixty five randomly selected tourists. Data was collected at
Sci. Technol. Arts Res. J., Oct-Dec 2012, 1(4):95-102

all possible places like tourist spots, restaurants, hotels and even at market place where ever we can spot the tourist and they were willing to respond the questioner. With the help of Interview Schedule twenty professionals from different aspects and rank of tourism professionals were interviewed. Data was tabulated and descriptive statistics techniques were used for data analysis.

\section{RESULTS AND DISCUSSION}

Profile of Tourists visiting Bahir Dar with reference to their age and sex were studied in table 1. It was found that among total tourists the ratio between male and female tourists was 60 to 40. Out of total tourists the majority $(75.03 \%)$ of them are of age group 18-64 Years. This points depicts that the Bahir Dar is the major destination for the young, middle age and upper middle age tourists. During survey it was observed that among this age group the major share was of middle age group people. The oldies ( $>64$ Years) are contributing more than one-fifth of the total tourists. The higher percentage of ladies and senior citizens depicts that tourist are quite confident about the security concerns. This is a big asset for a tourist destination especially in Africa. Children are extremely less (3.66 \%) in numbers. It shows that there is not much attraction for the children. Among the senior citizens 72 percent are male. This higher percentage of oldies shows the potential of the area suitable for the old people to rusticate. However the data also shows that it is not a major destination for the family as a whole and children as particular.

Table 01: Age and Sex of tourist's.

\begin{tabular}{|c|c|c|c|c|c|c|c|c|}
\hline \multirow[t]{2}{*}{$\begin{array}{c}\text { Age } \\
\text { Distribution }\end{array}$} & \multicolumn{4}{|c|}{ Male } & \multicolumn{2}{|c|}{ Female } & \multicolumn{2}{|c|}{ Total } \\
\hline & Number & $\begin{array}{c}\% \\
\text { out of } \\
\text { Male }\end{array}$ & $\begin{array}{c}\text { percent } \\
\text { out of } \\
\text { Total of } \\
\text { respective } \\
\text { age group }\end{array}$ & Number & $\begin{array}{l}\text { percent } \\
\text { out of } \\
\text { Female }\end{array}$ & $\begin{array}{c}\text { Percent } \\
\text { out of } \\
\text { Total of } \\
\text { respective } \\
\text { age group }\end{array}$ & $\begin{array}{c}\text { Total } \\
\text { Number }\end{array}$ & $\begin{array}{c}\text { Percent } \\
\text { out of } \\
\text { Total } \\
\text { tourists }\end{array}$ \\
\hline$<18$ & 3 & 3.03 & 50 & 3 & 4.56 & 50 & 6 & 3.66 \\
\hline $18-64$ & 72 & 72.72 & 58.54 & 51 & 77.52 & 41.46 & 123 & 75.03 \\
\hline$>64$ & 24 & 24.24 & 66.67 & 12 & 13.68 & 33.33 & 36 & 21.31 \\
\hline Total & 99 & 100 & 60 & 66 & 100 & 40 & 165 & 100 \\
\hline
\end{tabular}

Further, table 02 gives more information in this regard. To know more about the tourists attitude and their motive to visit Bahir Dar study try to know that with whom they are accompanying. The data revels that majority of tourists are coming with friends (66\%). it was observed that the larger chunk of this category was of youth below thirty years. Second most important category was of those tourists who are coming with group, largely organized by the tour 


\section{Dharmendra Kumar Dube}

operators at Addis as package tours, staying at luxurious hotels, moving with guides, having least interaction with locals. They are mainly the middle aged and old people. Loners or coming alone is the most interesting category, which contribute almost one-fourth of the total visitors. The most striking thing which was observed during survey was that larger chunk of the loners are of old aged people or upper middle aged visiting Bahir Dar for longer duration to relax. Families (unit of husband-wife and kids) were in a very small number.

Another interesting aspect of Bahir Dar was that it is just not a 'one time visit' type tourist destination; a large number of tourists are visiting here more than one time. During survey this aspect of tourists was given due consideration. table 03 shows the number of visits to Bahir Dar, reported by the respondents.

Table 02: Accompanying with (Whom).

\begin{tabular}{lcc}
\hline Accompany & $\begin{array}{c}\text { No. of } \\
\text { Tourists }\end{array}$ & $\begin{array}{c}\text { \% out } \\
\text { of total }\end{array}$ \\
\hline With family & 9 & 5.46 \\
With friends & 66 & 40 \\
and Spouse & 51 & 30.9 \\
With Group & 39 & 23.63 \\
Alone & $\mathbf{1 6 5}$ & $\mathbf{1 0 0}$ \\
\hline Total &
\end{tabular}

Table 03: Number of visits to Bahir Dar.

\begin{tabular}{lcc}
\hline \multicolumn{1}{c}{$\begin{array}{c}\text { Number } \\
\text { of Visit }\end{array}$} & $\begin{array}{c}\text { Nos. of } \\
\text { respondents }\end{array}$ & $\begin{array}{c}\text { \% of } \\
\text { respondents }\end{array}$ \\
\hline First Time & 92 & 55.76 \\
$\begin{array}{l}\text { Second Time } \\
\begin{array}{l}\text { More Than } \\
\text { two times }\end{array}\end{array}$ & 40 & 24.25 \\
\hline \multicolumn{1}{c}{ Total } & 33 & 19.99 \\
\hline
\end{tabular}

As usual largest percent $(55.76 \%)$ of the tourists are the first timers. Almost one-fourth of the respondents $(24.25 \%)$ visited second time to this town (table 4). The most striking feature was that almost one-fifth $(19.99 \%)$ of the total respondents have visited Bahir Dar more than two times. Most of them were either from upper middle age or the senior citizen. A good number of ladies of upper age group were also observed, they were largely here for a longer stay. These ladies were either single or with their friends, mainly ladies of same age group. The older people reported that due to non availability of
Sci. Technol. Arts Res. J., Oct-Dec 2012, 1(4):95-102

good and reliable medical facilities they avoid to stay longer. The lake side hotel managers have also reported about such tourists repeatedly coming every year to their hotels. Staying here for a week or two, or even more. They don't visit any tourist place, may be they have visited earlier, and are here just to rusticate.

Table 4: The continents from where the tourists have Arrived.

\begin{tabular}{lcc}
\hline Continents & $\begin{array}{c}\text { Number of } \\
\text { Tourists }\end{array}$ & $\begin{array}{c}\text { Percent out } \\
\text { of Total }\end{array}$ \\
\hline Europe & 51 & 30.9 \\
N. America & 45 & 27.28 \\
S. America & 15 & 9.11 \\
Africa & 27 & 16.36 \\
Others & 27 & 16.36 \\
\hline Total & $\mathbf{1 6 5}$ & $\mathbf{1 0 0}$
\end{tabular}

Tourists from different part of the globe are visiting Bahir Dar. To know their respective place of origin or from where they have come from, the tourists were categorized under different continents.

Largest numbers of tourists (30.9\%) are coming from European countries followed by $\mathrm{N}$. America. It was observed that from Europe, mainly they are from UK, Israel, Germany and Italy, and in case of N. America, they are from USA. From Africa, majorities are from neighboring countries of Sudan. Few of them are from Kenya, Nigeria and South Africa. From South America they are mainly from Brazil. Asians and Australians were included among others. The large population of Chines-Indians and Sudanese were not included as tourist, because they are the workers or students (Sudanese).

Motive of visit was also the concern of the study. They are purely coming for tourism or some other motive is also there, like search for job and explores the opportunities of business, meeting with relatives etc. Table 04 put light on this aspect.

Results (Table 5) shows that the major purpose of foreign visitors to Bahir Dar is tourism, resulting for 76.36 percent. A large number of Asians are visiting to this area for exploring the possibilities of business, especially in the sector of agriculture and leather industry. Africans are largely here for the exploration of job and business. 
Table 5: Purpose of visit.

\begin{tabular}{lcc}
\hline Purpose & Number & Percentage \\
\hline Tourism & 126 & 76.36 \\
Business & 21 & 12.73 \\
Others & 18 & 10.91 \\
\hline Total & $\mathbf{1 6 5}$ & $\mathbf{1 0 0}$ \\
\hline
\end{tabular}

Information and that to detailed and accurate information is the first step in the direction of putting a tourist destination in some ones tour itinerary. Planning of man starts with information of a place, and so the availability of information is a crucial point in development of tourism. Lack of information, un-complete information, hazy information and in-accurate information are bound to crop confusions and un-certainty, which no tourist will like to come across. This is more important when someone is venturing into Africa; where nature is at its wildest form and tribes at their primitive stage, governments are unstable, law and order system is frazil, un-certainty is common \& anything can happen any time even it may not be true; it is a general opinion in the mind of people of rest of the world. In fact media has been projecting a wild image of Africa. For longer period civil wars, ethnic violence, coup attempts by forces, flood, drought and famine, epidemics are frequent in Africa's pas. Lack of information is a major challenge for the tourism development in Africa as well in Ethiopia. In this context the sources from where tourists get the information and make their plan is very important.

Table 6 shows that the major source of information is internet used by 57 percent of respondents. Books related with tourism are almost equally important source. During discussion it was noted that internet was used as the primary information, further for detailed and accurate information they approached to books or tour operators. Article on magazines worked as a great starte...which most of them have come across during their pass time.

Table 6: Sources of information for Bahir Dar.

\begin{tabular}{|c|c|c|}
\hline Sources & $\begin{array}{c}\text { Number of } \\
\text { Respondents }\end{array}$ & $\begin{array}{l}\text { Percent of } \\
\text { respondents }\end{array}$ \\
\hline Internet & 57 & 34 \\
\hline Books & 54 & 32 \\
\hline Magazines & 15 & 9 \\
\hline $\begin{array}{l}\text { Internet and } \\
\text { Books both }\end{array}$ & 42 & 25.45 \\
\hline Others & 9 & 5 \\
\hline Total & 165 & 100 \\
\hline
\end{tabular}

The firsthand information given by their near and dears one was the most reliable source. Now the main issue is that which places tourists have visited. It is must to know that as per their prior information which are the places who get prominence in their itinerary. Table 7 gives interesting information in this regard.

- Lake Tana is the prime attraction of Bahir Dar. All tourists have gone for a boat trip to Lake Tana, visiting different destinations in the lake.

- War Memorial, on the bank of river Nile is the second most visited site by the tourists.

- Blue Nile water fall is the third most visited site $(72.72 \%)$. This is among the most propagated site by Ministry of Tourism and Culture Ethiopia, also depicted in the one Birr note of Ethiopia.

Open air market, Haile Selassie place and Traditional church school are the other visited sites. Here it's also important that for Boat Trip to Lake Tana, Blue Nile water fall and Haile Selassie are the spots for which tourist have to do special efforts while rests are within the premise of the town. It is also important that as the distance of the destinations in the lake is increasing the number of visitors is going down drastically. Though repeatedly it is said that the beauty of Lake Tana is in crossing the Lake. During survey a lot of respondents reported that they don't have much information about the attractions in the Lake Tana, even if they know little about it they don't have enough information to plan the trip. After reaching Bahir Dar shortage of time and money and limited availability of boat for longer trips is big problem. This problem is big enough for those how are not visiting with a package trip.

Visits of tourists to a spot largely depends on the prior information he gather from different sources or the places projected by the tour operators to him but after visiting the spots he develop his own opinion purely based upon his own liking and disliking of the spot. This opinion of tourist gives planner a big clue that which spot should be in the top priority for tourism development plan of that area and which spot is losing its importance, and why. For this information respondents were requested to give their priority (I, II and III) for the spots they have visited. 
Table 7: The tourist's spots visited by tourists.

\begin{tabular}{|c|c|c|c|}
\hline S.N. & Tourist Spots & $\begin{array}{l}\text { Visited by } \\
\text { respondents }\end{array}$ & $\begin{array}{c}\begin{array}{c}\text { Percent out of } \\
\text { total } \\
\text { respondents }\end{array}\end{array}$ \\
\hline I. & $\begin{array}{l}\text { Boat Trip to Lake Tana } \\
\text { (Two island Monastery } \\
\text { \& origin of River Blue Nile) }\end{array}$ & 165 & 100 \\
\hline II. & $\begin{array}{l}\text { Zige \& Narga Salasi } \\
\text { (It will include the spots of } 1 \text { ) }\end{array}$ & 21 & 12.73 \\
\hline III. & $\begin{array}{l}\text { Boat trip to Gorgora } \\
\text { (It will include the spots of } 1 \& 2 \text { ) }\end{array}$ & 9 & 5.45 \\
\hline IV. & Blue Nile Falls & 120 & 72.72 \\
\hline V. & H/Selassie Palace & 51 & 30.91 \\
\hline VI. & War Memorial & 125 & 75.75 \\
\hline VII. & Open Air Market & 90 & 54.54 \\
\hline VIII. & Traditional Church School & 3 & 1.82 \\
\hline
\end{tabular}

A result from the Table 8 gives useful information which is as follows. Maximum tourists (144) have given first priority to spot I, in lake Tana. After spot I, tourists have given maximum first priority to spot-II (12) followed by spot-III (9) in Lake Tana. No other spot got first priority by a single respondent. Spot-IV (Blue Nile Water fall) is prominent in second priority, followed by Spot$\mathrm{VI}$, war memorial but by percentage after Spot-IV it's the spot-II which receive importance. Its interesting that minimum number of tourists (3) visited spot-VIII Traditional Church school) but 100 percent have given it second priority which shows its potential. For third priority its again the Haile Saleshe Palace (56.86\%), War Memorial $(44 \%)$, and Blue Nile water fall are getting prominence.

Table 8: The priority (Ranking) of their liking to the tourists spots visited by tourists.

\begin{tabular}{|c|c|c|c|c|c|c|c|c|}
\hline S.N & Tourist Spots & $\begin{array}{l}\text { Visitors } \\
\text { to } \\
\text { Spot }\end{array}$ & $\begin{array}{c}\text { First } \\
\text { Priority }\end{array}$ & $\begin{array}{c}\% \text { of } \\
\text { total } \\
\text { visitors }\end{array}$ & $\begin{array}{l}\text { Second } \\
\text { Priority }\end{array}$ & $\begin{array}{c}\% \text { of } \\
\text { total } \\
\text { visitors }\end{array}$ & $\begin{array}{l}\text { Third } \\
\text { Priority }\end{array}$ & $\begin{array}{l}\% \text { of } \\
\text { total } \\
\text { visitors }\end{array}$ \\
\hline I & $\begin{array}{l}\text { Boat Trip to Lake Tana } \\
\text { (Two island Monastery \& } \\
\text { origin of River Blue Nile) }\end{array}$ & 165 & 144 & 87.27 & 12 & 7.27 & 9 & 5.45 \\
\hline II & $\begin{array}{c}\text { Zige \& Narga Salasi } \\
\text { (It includes the spots of } \\
1 \text { ) }\end{array}$ & 21 & 12 & 57.14 & 9 & 42.86 & 0 & --- \\
\hline III & $\begin{array}{l}\text { Boat trip to Gorgora } \\
\text { (It includes the spots } \\
\text { of } 1 \& 2 \text { ) }\end{array}$ & 9 & 9 & --- & $\begin{array}{c}--- \\
0\end{array}$ & --- & -- & --- \\
\hline IV & Blue Nile Falls & 120 & 0 & & 70 & 58.33 & 50 & 41.66 \\
\hline $\mathbf{V}$ & H/Selassie Palace & 51 & 0 & 0 & 13 & 25.49 & 29 & 56.86 \\
\hline VI & War Memorial & 125 & 0 & 0 & 47 & 37.6 & 55 & 44 \\
\hline VII & Open Air Market & 90 & 0 & 0 & 2 & 2.22 & 12 & 13.33 \\
\hline VIII & $\begin{array}{c}\text { Traditional Church } \\
\text { School }\end{array}$ & 3 & 0 & 0 & 3 & 100 & --- & --- \\
\hline
\end{tabular}




\section{Dharmendra Kumar Dube}

Here these numerical information demands subjective explanations clubbed with field observations for better understanding of the situations. Which are as follows,

The first priority of tourists are the lake Tana. All have give their first priority to it only. Here it must be noted that as the tourists visits deep into the Lake his priority get changed. Out of total 165 respondents 144 visited Spot-I only and were overwhelmed by that and given it first priority. 21 tourists gone beyond the trip of Spot-I, 9 of them gone upto Spot-II and given Spot-II as first priority and Spot-I as Second. 12 tourists visited up to Spot-III and given first priority to Spot -III, second Priority to Spot-II and third priority to Spot-I. It is clear that tourists want to visit deeper into the lake but they could not do it, reasons sought for it were- i). lack of information. ii). Availability of boat for small groups is difficult. iii). Even if boat is available it is very costly. A number of tourists reported that they come to have a clear cut information regarding islands in the Lake by the end of their stay in Bahir Dar.

The second interesting conclusion was the Blue Nile Water fall is still visited by a large number of tourists but it has drastically lost it's charm as most of the water of river Abbey (Blue Nile) is diverted to the hydro power station. Now it's a very small water fall giving not much satisfaction to the tourists. Matt Phillips correctly quoted it "The Blue Nile falls named by locals Tis Isat (water that smokes), ones mighty falls have now withered like an aged chain smoker". The unfortunately the glossy picture of the earlier mighty Blue Nile falls, is still projected in same way without any amendment in it.

It is not in fact the palace of Hile Saleshi which attracts tourists but the panoramic view of river Nile, its hippopotamus and Lake Tana. Unfortunately the palace is closed for the tourists.

It was interesting to note that only 3 out of 165 respondents visited the Traditional Orthodox Church school which is located at the heart of town, next to the St. Georges Church. But equally interesting that all three respondents given it the second priority after Lake Tana. Most of the respondents express their unawareness about it.

\section{CONCLUSIONS}

The study depicts that majority of the tourists are from Western Europe and North American countries, mainly from middle aged accompanying with friends, while the percentage of families, youth and children are quite less. Facts like high number of oldies visiting alone for
Sci. Technol. Arts Res. J., Oct-Dec 2012, 1(4):95-102

longer stay, tourists visiting more than one or two times shows the potential of this area for peaceful rustication. Internet is the prime source of information for the tourists. Lake Tana is the prime attraction followed by the War memorial, Blue Nile Water Fall, Haile Saleshi Palace. Deeper they go into the lake, more they like it yet only few cross the Lake. Reasons shot are lack of information, non availability of small boats for smaller groups or singles and if so they are quite costly. There is no scope of break journey at any of the island. Blue Nile water fall, highly projected by tourist authorities and visited by a huge percentage of tourists have lost its charm due to the divergen of river water for hydro power station. Similarly it's not the palace of the Haile Saleshi but the panoramic view of river Nile and Hippopotamus in the river which give them satisfaction. Due to unawareness only few tourists visited Orthodox Church School but they expressed their high liking for it. Based on the findings study gives following recommendation-

- There must be compatibility between the projected sites by tourism authorities and the sites liked by the tourists.

- Development of better facilities for senior citizens like medical facilities and nursing homes, Jims, transportation and communications, guests houses are must.

- Development of some major attractions for the kids and youth, like amusement park, water park, jungle camp or camp sites near lake shore, promotion of water sports in lake Tana like rowing, yachting, pulling, water safari, jet boots and even traditional Papyrus boat expedition may attract a huge number of youth and school children.

- The surrounding of Bahir Dar could be developed as a nice place for adventure sports like rock climbing, gliding and micro aero sports. River Nile could be explored for rafting.

- Millennium park, identified at the source of Blue Nile should be developed for the exposure of swamp ecology, flora and fauna.

- Information dissemination centers at the major cities of Europe and North American countries should be established.

- As internet is the prime source of information so proper development and continuous update of website is must. Tourism department should establish a cyber centre with well verse profession team for promptly and satisfactory entertaining the queries of the tourists. 


\section{Dharmendra Kumar Dube}

- Cheaper options for the smaller groups of tourists should be provided.

- One well developed resort is required at Daq island which could serve as the base to explore the lake and its islands.

- Spots like 'Traditional Church School', 'Open air market and other less known attractions need a proper projection in tourist department brochure.

\section{REFERENCES}

Bahir Dar and Lake Tana Ethiopia ANRS tourism commission (2005). Central printing press. Addis Ababa.

Bahir Dar Town Central and Tourism Bureau (BDTCB) (2011). Un published reports.

Boniface, B.G and Cooper, C. (1987). Geography of Travel and Tourism, Heinemann, London.

Boniface, P and Fowler, P. (1993). Heritage And Tourism In The Global Village. Routledge. London.

Boniface, P. (1995). Managing Quality Cultural Tourism, Routledge, London.

Burkart, A and Medlik, S. (1975). Management of Tourism. Heinemann. London.

Burton, R. (1995). Travel Geography. Pitman. London.

Cooper (2005). Tourism, Principles and Practice. Pitman. London.

Ethiopia: Towards a Strategy for Pro-Poor Tourism Development (2006). Report No. 38420-ET. Prepared for the Government of Ethiopia by the World Bank.

Ethiopian Economic Association (2007). Proceedings of fourth international conference on the Ethiopian economics, Volume I.

Foster, D. (1985). Travel And Tourism Management. Macmillan Education. London .

Golledge, R.G and Stimson, R.J. (1997). Spatial Behaviour: A Geographic Perspective. Guilford Press. New York, USA.

Hall, C.M. (2000). Tourism Planning: Policies, Processes and Relationships. PrenticeHall. Harlow.
Sci. Technol. Arts Res. J., Oct-Dec 2012, 1(4):95-102

Hall D, Richards G. 2000. Toursim And Sustainable Community Development. Routledge. London.

Holden, A. (2000). Environment \& Tourism. Routledge. New York, USA.

Howie, F. (2003). Managing the Tourist Destination. Continuum. London.

Lickorish, L. (1991). Developing Tourist Destinations: Policies and Perspectives, Longman. Harlow.

Lofgren, O. (1999). On Holiday: A History of Vacationing. Berkeley California, University of California.

Marion, L. (2009). Tourism Statistics: Challenges and Good Practices at Regional Workshop for South East Asian countries, UNWTO/UNSD WS Vientiane.

Mohamed, A. (1996). Spectrum Gude to Ethiopia. Camerapix Publishers International. Nairobi Kenya.

Mohamed, Z. (1998). Introduction to tourism and hotel industry. Vikash publishing house, India.

Prentice, R. (1997). Cultural And Landscape Tourism: Facilitating Meaning. Routledge. London.

Shaw, G and Williams, A. M. (1994). Critical Issues in Tourism: A Geographical Perspective. Blackwell. Oxford.

Shaw, G. and Williams, A. (2004). Tourism and Tourism Spaces. Sage. London.

World Tourism Organization (1998). National and regional tourism planning, methodologies and case studies. Rotlrdge. New York.

WTO (1998). Tourism Services, S/C/W/51, September. Geneva: World Trade Organisation.

WTO and UNCTAD (2001). Tourism in the Least Developed Countries, Madrid: World Tourism Organisation.

WTO/OMT (2002). Tourism and Poverty Alleviation Report, Madrid: World Tourism Organisation.

Yabibal, M. (2010). Tourist Flows and Its Determinants in Ethiopia. Ethiopian Development Research Institute-Working Paper-01. Addis Ababa, Ethiopia. 